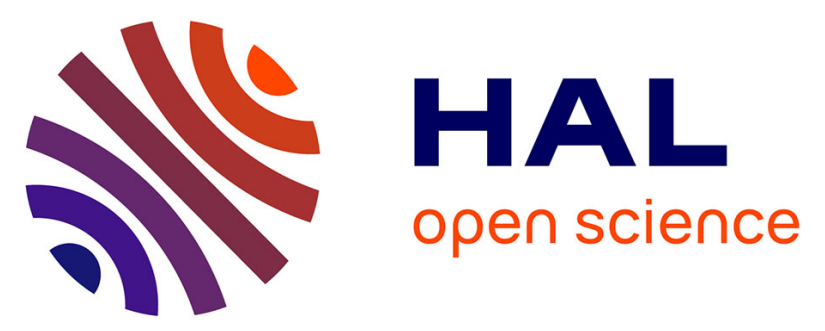

\title{
PUMP-DEPENDENT SPECTRAL DISTRIBUTION AND TIME BEHAVIOUR MEASUREMENTS IN HIGH POWER Ar-Xe LASER UNDER E-BEAM AND E-BEAM SUSTAINED DISCHARGE PUMPING
}

\author{
N. Sazhina, N. Ustinovsky, I.V Kholin, A. Chugunov
}

\section{To cite this version:}

N. Sazhina, N. Ustinovsky, I.V Kholin, A. Chugunov. PUMP-DEPENDENT SPECTRAL DISTRIBUTION AND TIME BEHAVIOUR MEASUREMENTS IN HIGH POWER Ar-Xe LASER UNDER E-BEAM AND E-BEAM SUSTAINED DISCHARGE PUMPING. Journal de Physique IV Proceedings, 1991, 01 (C7), pp.C7-590-C7-590. 10.1051/jp4:19917157 . jpa-00250833

HAL Id: jpa-00250833 https://hal.science/jpa-00250833

Submitted on 1 Jan 1991

HAL is a multi-disciplinary open access archive for the deposit and dissemination of scientific research documents, whether they are published or not. The documents may come from teaching and research institutions in France or abroad, or from public or private research centers.
L'archive ouverte pluridisciplinaire HAL, est destinée au dépôt et à la diffusion de documents scientifiques de niveau recherche, publiés ou non, émanant des établissements d'enseignement et de recherche français ou étrangers, des laboratoires publics ou privés. 


\section{PUMP-DEPENDENT SPECTRAL DISTRIBUTION AND TIME BEHAVIOUR MEASUREMENTS \\ IN HIGH POWER Ar-Xe LASER UNDER E-BEAM AND E-BEAM SUSTAINED DISCHARGE \\ PUMPING}

N.N. SAZHINA, N.N. USTINOVSKY, I.V. KHOLIN and A.Yu. CHUGUNOV

P.N. Lebedev Physical Institute, Leninsky Prospect 53, Moscow 117924, USSR

The high pressure Ar-Xe laser on XeI transitions of the 5d-6p manifold is attractive because of its high efficiency .5\%, high specific energy $\sim 8 \mathrm{~J} / \mathrm{I}$ and wavelength ranging from 1.73 to $3.51 \mu \mathrm{m}$. The purpose of our study is to investigate spectral distribution and time behaviour of Ar-Xe laser radiation under electron-beam ( $E$-beam) and $\mathrm{E}$-beam sustained discharge (BBSD) pumping with E-beam ourrent density $j$ being varied in $j=0.01 \div 1.7 \mathrm{~A} / \mathrm{cm}^{2}$ range.Total pressure $p$ and $X e$ fraction $\delta$ varied in $p=1 \div 3.5 \mathrm{~atm}, \delta=10^{-1} \div 10^{-4}$ ranges. We used unstable telescopic resonator with $M=2$, active volume being $7.5 \mathrm{I}$. In the case of E-beam pumping of the optimal mixture with $p=3.5 \mathrm{~atm}, \mathrm{~B}=$ $10^{-2}$ and high current density $j=1.7 \mathrm{~A} / \mathrm{cm}^{2}$, the main part of the laser energy is concentrated in two lines with $\lambda=1.73 \mu \mathrm{m}$ (90\%) and $\lambda=2.63 \mu \mathrm{m}$ (10\%). The decreasing of $j$ up to $0.04 \mathrm{~A} / \mathrm{cm}^{2}$ is followed by the laser energy redistribution from $1.73 \mu \mathrm{m}(2.63 \mu \mathrm{m})$ line to $2.65 \mu \mathrm{m}(3.37 \mu \mathrm{m})$. Further decreasing of $\mathrm{j}$ up to $0.01 \mathrm{~A} / \mathrm{cm}^{2}$ leads to replacement of the line $\lambda=2.65 \mu \mathrm{m}$ by the line $\lambda=3.37 \mu \mathrm{m}$ (90\%).For the whole set of experimental conditions the following is true: despite the initial spectral distribution for all $j$ values, EBSD pumping leads to spectral distribution similar to the case of high current E-beam pumping with $j=1.7$ $\mathrm{A} / \mathrm{cm}^{2}$.We may conclude that for both cases the spectral distribution depends only on the pump power. It is not oocasional coincidence and finds its explanations in terms of discussed Ar-Xe laser recombination model. 